\title{
SOME NATIONAL PARKS OF NORTH AMERICA
}

\author{
By E. P. GeE
}

\section{Tine United States}

There was a story told sometime during the last century of an old and impoverished North American prospector, who was asked on his return, what he had to show for all the time he had spent out west. His answer was "I have seen the Rocky Mountains". I myself have recently returned from a tour of some of the national parks of North America and the impression of wildness, grandeur and beauty remains.

In some of the zoological gardens and natural history museums of New York, Philadelphia, Washington, Chicago and Denver I got a good idea of the types of wild life and natural habitats which I was later to see in the west. This was particularly so in the museum of Denver, where recent exhibits cleverly showed the ecology of the different "life zones" through which I was to travel during the next few weeks.

The first park I visited was, appropriately enough, Rocky Mountain National Park of 399 square miles not far north-west of Denver. And as I was taken there by no less a person than the Director of Denver's museum, I was given a most fitting introduction to the Rockies as his car climbed from the aspens of the Transition zone, through the Canadian zone where lodgepole pines gave way to Douglas fir, through the Engelmann spruce of the Hudsonian to the bleak Alpine zone.

Dr. Alfred Bailey, whose intimate knowledge of the Rockies is equalled by very few, pointed out the more interesting fauna and flora as we passed along. Eventually we were above the timber line on the second highest of all park roads-the Trail Ridge Road which ascends to 12,183 feet. Here we left the road and walked (rather breathlessly at this elevation) up the mountain side. We watched marmots, chipmunks, hayharvesting rodents called pika and two cock ptarmigan (southern white-tailed). Later we found a hen ptarmigan on her nest; she remained unperturbed even when we gently and carefully lifted her up to see her five eggs.

In this very accessible park where the mountains rise to 14,255 feet we could see all around us, every time the grey clouds parted, snow-covered peaks shimmering in the afternoon sunlight after the rain.

From here to the next park on my itinerary it took me a day 
and a night in the train, and then a bus journey of half a day through national forests. Most of the mountain national parks of the United States are surrounded by Federal-owned national forests, in which planned exploitation of timber, grazing and hunting are allowed. These forests act as a "buffer zone" round the national parks.

\section{Grand Teton}

I will never forget the mountains, lakes and wild flowers of Grand Teton National Park, 468 square miles. It was now mid-July, and this was truly springtime in the Rockies. Snow still lingered in picturesque patches on the peaks of the Teton mountain range, and these were often beautifully reflected in the lakes beneath. And every meadow on the valley floor simply blazed with wild flowers in full bloom-mountain arnica, scarlet gilia, buckwheat, penstemon, Indian paintbrush, columbine, hollyhock and a whole host of others, all lush, fresh and totally unspoilt by any kind of grazing or picking.

So marvellous were these wild flowers, which even excelled those I had seen in Switzerland a few years back, that they were in some measure a compensation for not seeing deer, bison and wild sheep. To see these animals at low elevations one should visit the parks in the spring or fall months. Only in a special enclosure in this park could I see elk (wapiti) and bison, for about two dozen of each of these species are kept here for research. Marmots and chipmunks were, of course, plentiful, as well as birds of many species.

On my last day I saw a pair of trumpeter swans with the family which they had raised on a tiny lake, only a quarter of a mile from a vast camping ground thronged by humans and their transport.

\section{Yellowstone}

From Grand Teton National Park one crosses directly into Yellowstone, of 3,472 square miles, which deserves the honour of being known as the most famous of the world's national parks. Yellowstone has everything. There is the famous Yellowstone river which has carved an awe-inspiring canyon, only surpassed in size and grandeur by the Grand Canyon of Colorado. 'There are waterfalls of up to $\mathbf{3 0 8}$ feet in height, nearly twice as high as Niagara.

Yellowstone National Park is one of the world's three areas where numerous geysers, hotsprings and similar phenomena occur, the others being Iceland and New Zealand. Here is 
living geology, geology of the present as well as of the past. Old Faithful geyser, which erupts to 180 feet, at intervals which average 65 minutes, is a never-failing source of attraction, part of the appeal being the uncertainty of its timing.

Yellowstone, in addition, has plenty of wild life which can be seen by visitors-even along the highways. A few pronghorn antelopes and moose were seen by our party, though not elk and bison, for these had moved up to their summer range. Black bears, which can be black, brown or cinnamon in colour, were seen all along the highways waiting for food from passers-by.

To me, I must confess, the most memorable thing about Yellowstone was a tiny museum and an old camp-site at a place called Madison Junction. In this museum was dramatically exhibited a scene which took place at a camp on the nearby Firehole River on 19th September, 1870, when a semi-official expedition went there to verify the remarkable tales of canyons and geysers. At this spot, while the members of the expedition were planning to stake their claims for the valuable lands they had just visited, one of them proposed that the place should belong to the nation as a whole. The idea caught on. At that place and at that moment the national park idea was born; two years later the Yellowstone National Park was constituted.

My last day at Yellowstone was spent in the company of park naturalist David Condon, the park biologist and the park landscape architect. Going about with these men I got some insight into their administrative problems-problems affecting control of insects such as spruce budworm and blackheaded budworm which attack trees, control of forest fires both manmade and natural and of overgrazing by elk and bison. The matter under immediate investigation was the deterioration of the vegetation in some of the valleys which form the winter range of the elk. Small preservation plots were being marked out to demonstrate the contrast between fenced areas and those grazed by the 10,000 elk and 625 bison in the park.

\section{Glacier}

After a visit to the National Bison Range at Moiese, where I saw elk and pronghorn as well as bison, I travelled north to Glacier National Park. Though the mountains here are not so high as in Grand Teton, they are rugged, glacier-covered and are reflected in beautiful lakes. This 1,562 square mile park is altogether most spectacular and inspiring, while the journey along Going-to-the-Sun Highway (a grand name) over the 
Continental Divide at Logan Pass (6,664 feet) is an experience which can never be forgotten.

Of wild life in this park we saw one bear and one Rocky Mountain bighorn sheep. The wild flowers were second only to those of Grand Teton. In particular the fireweed at lower elevation, and the bear grass and glacier lily in higher alpine meadows were then just at their very best.

The national parks of United States and Canada are all created, owned and managed by the Federal Governments. A national park belongs to the whole country, just as do the National Museum, the National Library, the National Zoological Gardens and National Art Gallery.

In national parks food, accommodation, shopping facilities, petrol, boats, horses and a host of other services for the visiting public are provided by private enterprise. Everything is let out to "concessioners" who pay a fee and are required to maintain specific standards of service and to have their rates and prices approved by the authorities.

\section{Wilderness}

A feature about certain parts of North America is their wildness, vastness, remoteness and primeval grandeur. This applies to areas both in the national parks, where roads have not spread the tentacles of civilization, as well as to areas outside which are still unspoilt and unexploited by man, where Nature reigns supreme. Such unspoilt areas are known as " wilderness".

There is a strong belief in North America that wilderness is a "valuable national resource that belongs to the people and that its preservation-for educational, scientific and recreational use-is part of a balanced conservation programme essential in the survival of our civilized culture ". While in the Grand Teton National Park I had the good fortune to mect and listen to Olaus Murie, the renowned biologist-artist-author who is president and director of the Wilderness Society, one of the most important of the many nation-wide societies in the United States dedicated to the cause of nature conservation.

\section{Mission 66}

The large and ever increasing number of visitors to the national parks of the United States has brought many problems in its wake. In 1940 there were 25 million visitors to the parks, in 1955, 50 million; in 1966 it is expected that 80 million will come. So a vast 10-year conservation programme to be completed in 1966, called "Mission 66", has been devised. New 
and carefully planned public buildings, camp grounds, picnic areas, are being made and new highways and trails constructed, without spoiling the natural beauty of the parks but to permit the " wisest possible use, maximum enjoyment for those who use them, and maximum preservation of the scenic, scientific and historic resources" of the national park system.

Another problem is brought about by the seasonal rush of visitors in the summer months. From where come the large numbers of hotel waitresses, maids, porters, attendants, bus drivers, extra park naturalists and other staff, required only in the busy season? How can such an efficient and neatly uniformed staff be obtained for only a few months to deal with the 50 million or more visitors to the country's national parks ? A notice in the log cabin of my first hotel revealed to me that "Our maids, waitresses and bus boys are college students from various parts of the country".

Each summer vacation, undergraduates and graduates of universities, school teachers and even a few professors pour into the national parks, to do a good job of work which is of benefit both to themselves and to their great country.

One of the most interesting features of the national parks in the United States is the "Interpretive Division" of the National Parks Service. Under this there are naturalist services in all the parks. These include roadside museums, information stations, guided informal nature walks, campfire programmes and illustrated evening talks. The object is to help the public to appreciate, enjoy and understand their national parks. One night while I was in Glacier one of the park naturalists was giving a talk to over 100 people round the campfire when a grizzly bear strode into the circle. The naturalist, whose subject that night was "What to do and see in Glacier", got the crowd to move to one side carefully and slowly away from this unexpected visitor. The bear then left. Possibly it turned up the wrong night, for later on in the week the subject was "Animal Life of the Park".

\section{Canada}

Glacier National Park of the United States and Waterton Lakes National Park of Canada jointly form an International Peace Park of the two countries. Though there is no direct internal road connecting them, it only takes a couple of hours to motor out of Glacier, complete the dual customs formalities at the international boundary and then drive round to the Canadian park. 


\section{Waterton" Lakes}

The mountains and lakes of 204 square mile Waterton Lakes National Park were grand, particularly the snow-capped and glacier-cut mountains at the head of Cameron Lake. Here were true solitude and serenity, with just enough man-made accommodation and amenities.

In the morning we stopped on the road to Cameron Lake and from our car watched a group (or is it flock ?) of Rocky Mountain bighorn sheep which was visiting a roadside salt-lick nearby. Ewes, some with lambs, were in the majority, but there was a young ram about one year old and later the stately master ram came into view. Unencumbered by the woolly coat of domestic sheep, these neat creatures enchanted us by their graceful and effortless movements as they nimbly climbed up and down the rocky and precipitous mountain side.

\section{Banff}

My Canadian friend had to return to his work in Lethbridge, and so I proceeded on my own by bus to Banff National Park. The town of Banff is a neon-lighted place with shops, cinemas, banks, etc., and contains a resident population of about 2,500 people, apart from visitors. Banff town is a persistent headache to the park authorities, who have to assume full responsibility for its administration and public services. What a pity it was not excluded from the national park area when the park was finally constituted at its present size.

Banff is Canada's oldest national park, having been created in $\mathbf{1 8 8 7}$ to take in the hotspring area of 260 square miles. Later it was enlarged to its present size of 2,564 square miles. In spite of the existence of the town of Banff, the Canadian-Pacific Railway and the Trans-Canada Highway, the park is a magnificent piece of unforgettable grandeur.

Although the national park idea was first developed by the United States, Canada can boast of being the first country in the world to create a special government department to administer her parks. A special branch of the Ministry of the Interior was formed in 1911, some six years before the National Parks Service in the United States. Although Canada has 29,000 square miles of national parks compared with the 39,000 square miles in the United States, development in the northern country is naturally behind that of her larger and richer sister in the south.

From Banff I visited Lake Louise and Moraine Lake-two 


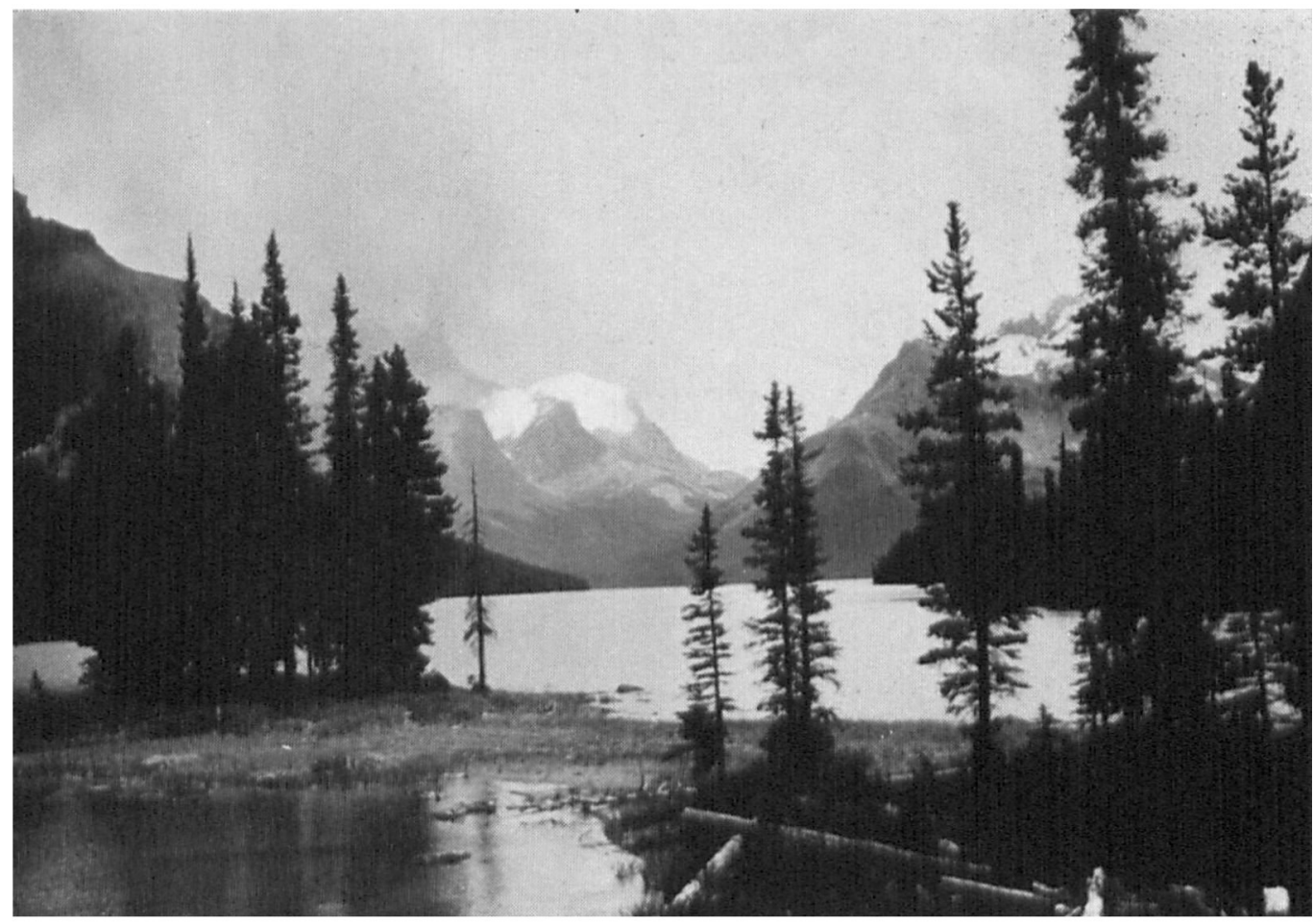

Photo: F. P. Go.

A RAINY IAY AT LAKL MALIGNE IN JASPLR NATIONAL, PARK.

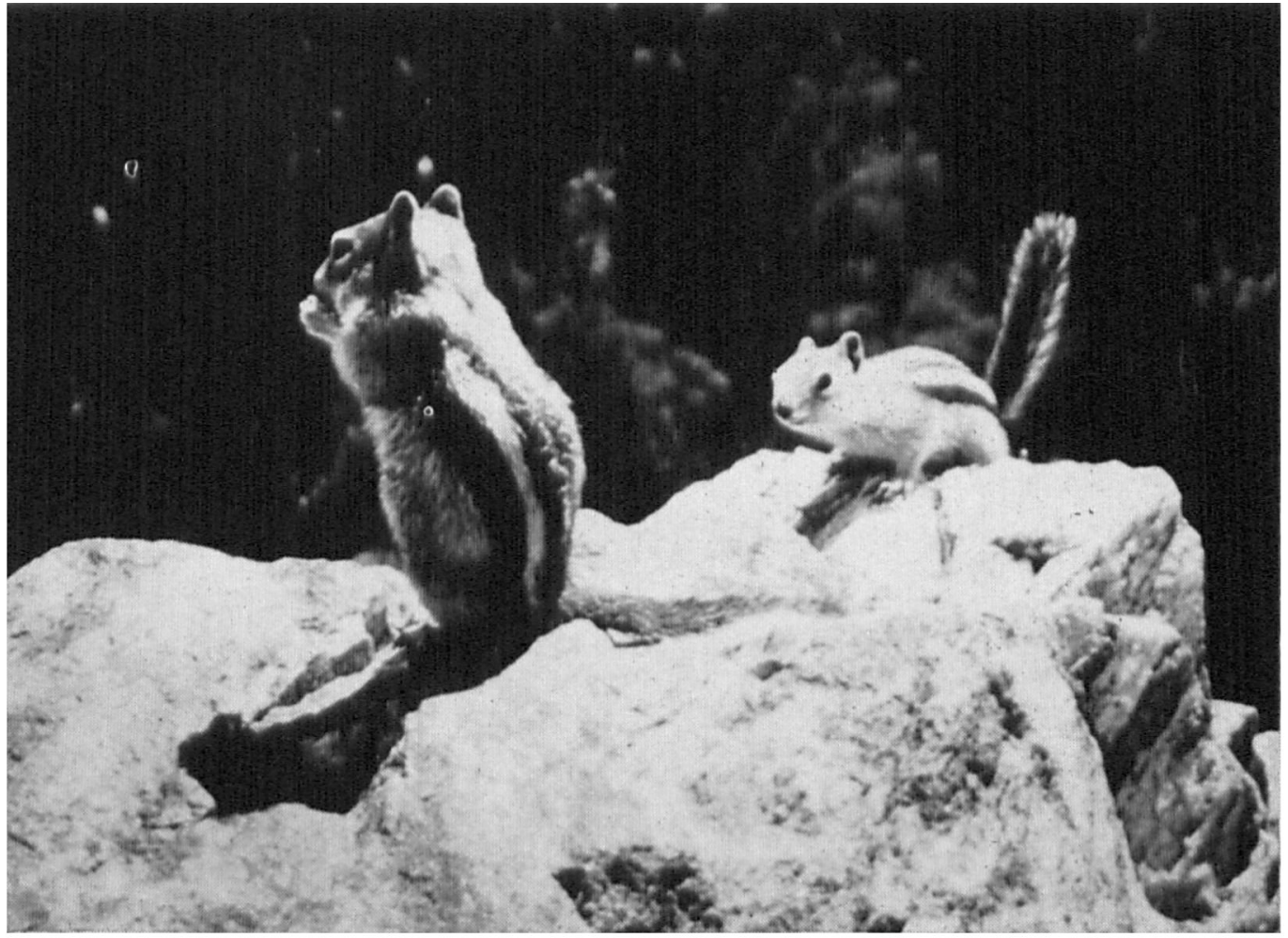

Whoto: L.P. Ger.

(HIPMINKS, MO'THER ANI) BABY. 


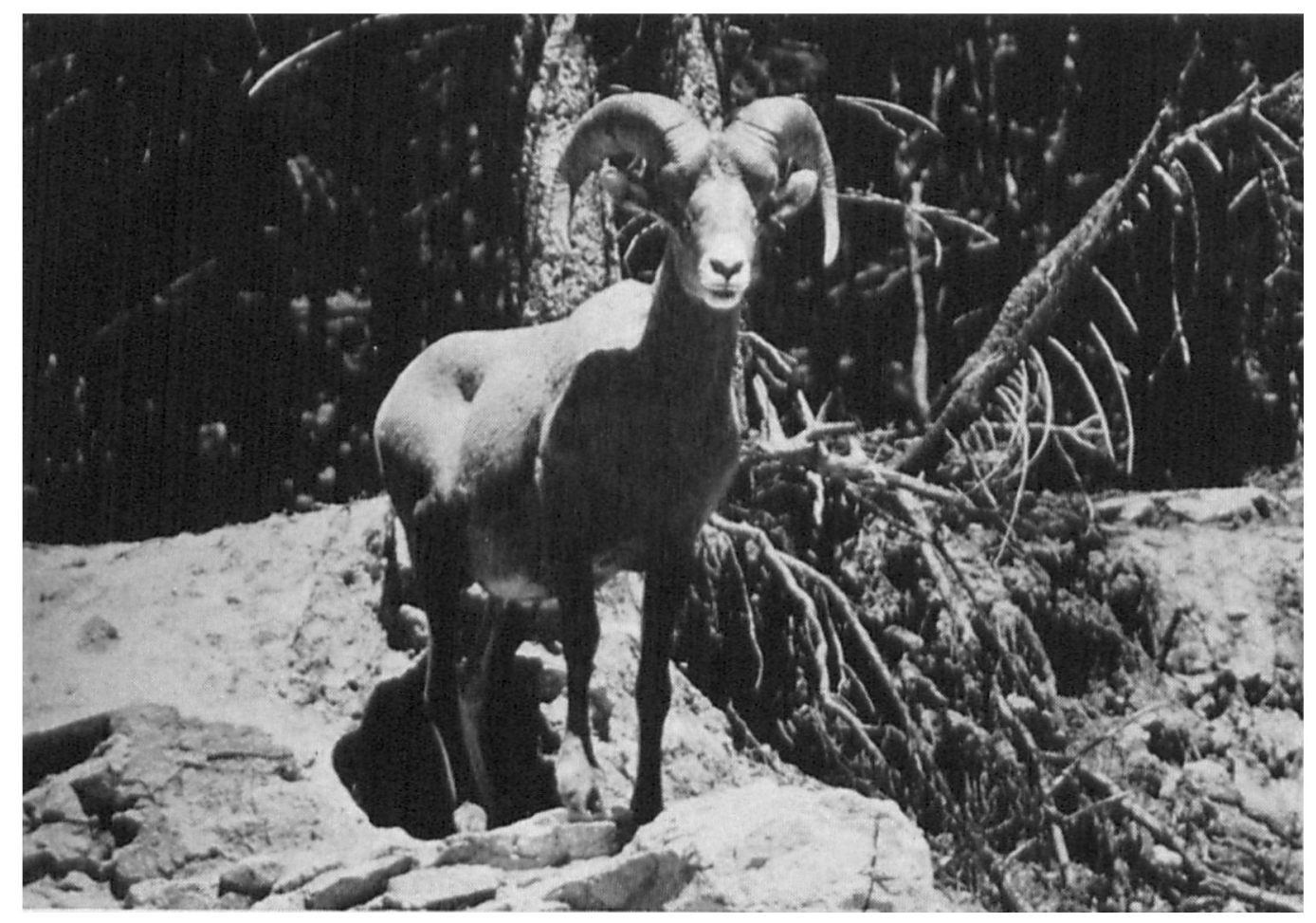

Photo: L. P. Ge'.

ROCKY MOT'NTIN BIG-HORN SHEEP

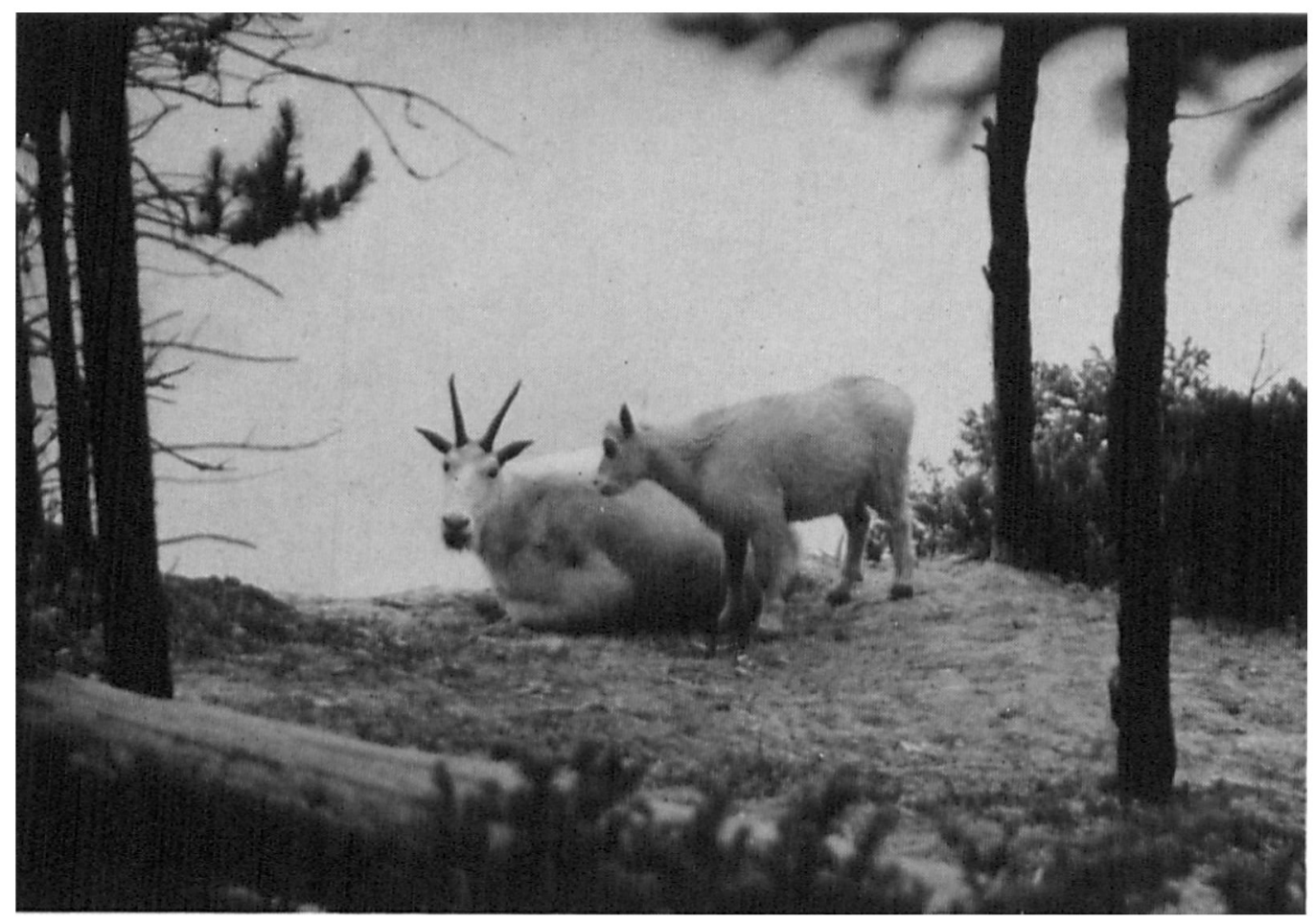

ROCKY MOI NTIN GOAT.

Phote: ES Ge 
fine glacial lakes of bright emerald green. This peculiar but pleasing colour is said to be caused by the melting glaciers, the very fine deposit particles remaining suspended in the water. Going on from Lake Louise I went to a sheet of water actually called Emerald Lake, in Yoho National Park, of 507 square miles, in British Columbia. - This journey to Emerald Lake takes you over the Continental Divide, where a tiny brook bifurcates (after some slight artificial assistance, I believe !) with one half running east into the Atlantic and other west into the Pacific.

Following the western streamlet, we went down the famous Kicking Horse Canyon where the river of that name rages furiously down from the mountains. This is one of the three passes through the Canadian Rockies. Here the railway winds its way through a spiral tunnel inside the mountain. Takakkaw Falls, 1,200 feet high and the third highest in the world, loomed up through the clouds above us. It is a wild and awe-inspiring place.

\section{Jasper}

To get to Jasper, Canada's largest park of 4,200 square miles, I motored along the new Banff-Jasper Highway, 183 miles of spectacular mountains, gleaming glaciers and lakes. I will refer only to the Columbia Icefield. Here, at the boundary of Banff and Jasper, there is the largest sheet of ice south of the Arctic Circle, over 120 square miles in extent. Known as "the roof of the world " and "the mother of rivers", this remnant of the Ice Age furnishes the headwaters of rivers flowing into three oceans : the Saskatchewan into the Atlantic, the Columbia into the Pacific and the Athabasca into the Arctic. One motors from the highway to the edge of the Athabasca Glacier, and then can ride two and a half miles up the glacier in a "snowmobile ", a ten-seater vehicle with skis in front and caterpillar tracks behind.

My hotel near Jasper town was in a little glade of lodgepole pines overlooking the Athabasca river. It consisted of log cabins clustering round a central and larger log cabin restaurant. Here were staying about twenty-four visitors-and nine bears. I met most of the visitors during my four-day stay, but was happier observing the bears, which are all black up here in Canada, and not a mixture of black, brown and cinnamon as further south.

Notices are displayed all over the parks of the United States and Canada warning visitors not to touch or feed the bears- 
about 100 visitors out of $1 \frac{1}{2}$ million get hurt by bears every year in Yellowstone. But there were no notices warning the bears not to touch us, and one day one of the bears at our lodge came up to me. I stood perfectly still, my hands in my pockets so that I could not be accused of touching it. It came up and touched me, front paw on my foot, sniffing my pockets. It was about to turn away, when another enormous bear charged furiously. I stepped aside-unnecessarily as the second bear was apparently charging the first. In no time at all the first bear was at the top of a convenient pine tree and the second bear half-way up after it. I continued my watching with even greater interest.

The mountains of the Canadian Rockies are not so high as those of the United States, but being further north they have more snow and glaciers in the summer months and therefore appear wilder and more spectacular.

A never-to-be-forgotten journey was the one I did to Lake Maligne. So beautiful is it, that it is well worth the long and slow journey-seventeen miles in a large bus, ten miles across Bad Medicine Lake, eleven miles by a small bus and finally seven miles along the lake. Then back the same way. But this is probably one of the most beautiful lakes in the world.

It would not be right to attempt to compare the mountain national parks of Canada with those of the United States. The parks of neither country are "better" than those of the other : rather the parks of both countries are complementary to each other. In fact the parks of the Canadian Rockies are a continuation of those further south, and particularly resemble Glacier National Park in general character. Like Glacier, they are less crowded and therefore quieter.

In Canada I missed the extensive park interpretive services of the United States' parks-the park naturalists, roadside information stations, guided nature walks and so on, though I was told these are all due to come shortly.

In Canada, on the other hand, I saw more wild life. Apart from the numerous marmots, pika and chipmunks, and apart from the bears and a few moose and pronghorns (and a solitary coyote) in Yellowstone, and one sheep and one bear in Glacier, I saw no wild animals in the United States. They were mostly up in their summer ranges. But in the Canadian parks I came across animals every day-mule deer in Waterton Lakes and Jasper, elk (wapiti) in Banff (even in the town itself !), bighorn sheep in Waterton Lakes and Banff, skunk in Waterton Lakes and wild goats in Jasper. And black bears, of course, in both Banff and Jasper. 
The park authorities of both countries appear to view these seen-near-the-highway animals almost with indifference. They are everyday sights to them, not really wild animals but " panhandlers" in United States and "highway bums" in Canada. But to the average park visitor, who probably comes from a place where there is no wild life, they are a never-failing source of wonder and delight.

I was able to gauge this from the reactions of the public when I travelled by bus. At the sight of lofty glacier-covered mountains towering above us, or beautiful lakes gleaming in front of us, people looked with appreciation and sometimes with awe. But whenever we saw wild animals, nature's living masterpieces of gracefulness and screnity, they rose up from their seats and rushed forward for a clearer view. Cameras of all sorts and shapes were suddenly produced from nowhere, and the bus simply buzzed with conversation for some time afterwards. Wild life, I affirm without any hesitation, occupies first place among the attractions of the North American national parks. Surely it is a triumph of conservation that these wild animals, which a few decades ago were nearly hunted out of existence, should have had their confidence in man so fully restored as to take food from his hand.

\section{LASTING IMIPRESSION}

And so, on the return journey across the world back to India, the time had come to take stock of what I had seen. What had impressed me most? Was it the unbelievable sight of meadow upon meadow of freshly glittering wild flowers, with the snow-streaked Grand Tetons beyond? Was it the awe-inspiring Grand Canyon of Yellowstone with the river sparkling far below against the setting sun ? Or the Going-tothe-Sun Highway in Glacier, with everything that could be desired in an ideal national park?

Can I forget the magnificent elk stags of Banff with velvety antlers of incredible size, or mule deer does confidingly accepting food from the hands of young girls; or the lakes of unbelievable emerald green encircled by pine-forested, glaciertipped peaks in Banff and Jasper?

All these and many more memories will always remain. But decpest impression of all was that of the North American owners and makers of these national parks. Previous ideas of dollar materialism got from the "movies" and from casual meetings with Americans in other countries, quickly vanished 
when I met the real North Americans in their homes and in the national parks. They had the power to exploit and despoil all the grandeur and wilderness of their country. Instead they have created the finest system of preserving at least some of it for ever and are thereby showing the rest of the world an example which none of us should fail to heed. 